\title{
FDG PET and the genetics of dementia
}

\author{
Benedetta Nacmias • Valentina Berti • \\ Irene Piaceri $\cdot$ Sandro Sorbi
}

Received: 9 May 2013/Accepted: 2 July 2013/Published online: 16 July 2013

(C) Italian Association of Nuclear Medicine and Molecular Imaging 2013

\begin{abstract}
Dementias are the most common neurodegenerative diseases and they are increasingly becoming a major public health problem. The most common form of dementia, affecting over 20 million people worldwide, is Alzheimer's disease (AD). $\mathrm{AD}$ is a neurodegenerative disease of the central nervous system mainly found in older adults, with an incidence that increases with age. With the development of newer technologies, including genetic screening technologies and PET/MRI scanning, the role of genetic studies and neuroimaging is being redefined; indeed, these approaches are able to provide support not only in the clinical diagnosis of dementia, but also in its presymptomatic evaluation. Many researchers agree that early identification of $\mathrm{AD}$, before abnormal accumulation of amyloid and tau proteins, could provide an opportunity to hinder the progression of the disease. $\left[{ }^{18} \mathrm{~F}\right] 2$-fluoro-2deoxy-D-glucose (FDG) PET studies have shown that decreased glucose metabolism in $\mathrm{AD}$ precedes clinical diagnosis and that the degree of clinical disability in $\mathrm{AD}$ correlates closely with the magnitude of the reduction in brain glucose metabolism. Data on presymptomatic mutation carriers from families with known early-onset autosomal dominant AD (familial AD) show reductions in the cerebral metabolic rate of glucose (CMRglc), consistent with the expected AD PET pattern, in the absence of severe
\end{abstract}

B. Nacmias $(\varangle) \cdot$ I. Piaceri · S. Sorbi

Section of Neuroscience, Department of Neuroscience, Psychology, Drug Research and Child Health, University of Florence, Viale Pieraccini 6, 50139 Florence, Italy

e-mail: nacmias@unifi.it

V. Berti

Nuclear Medicine Unit, Department of Biomedical, Experimental and Clinical Sciences, Viale Morgagni 50, 50134 Florence, Italy atrophy on MRI. These results suggest that PET CMRglc measures have the potential to serve as preclinical biomarkers of dementia, useful also for tracking disease progression. This review highlights the role of genetics and FDG PET in understanding the pathogenesis of dementia.

Keywords FDG PET - Dementia · Gene ·

Alzheimer's disease

\section{Introduction}

Dementias are the most common neurodegenerative diseases and they are increasingly becoming a major public health problem. These diseases are, in fact, one of the major causes of disability in the general population and it is estimated that their prevalence, currently standing at 35.6 million people worldwide, will increase to 115 million by 2050 [1].

The most common form of dementia, affecting over 20 million people worldwide, is Alzheimer's disease (AD). AD is a neurodegenerative disease of the central nervous system mainly found in older adults, with an incidence that increases with age. From a clinical point of view, it is characterized predominantly by initial deficits in episodic memory, followed by progressive involvement of semantic memory, attention, executive function and language skills. Disease progression, lasting an average of 10 years, leads to the death of the individual, usually due to intercurrent infections. The key features of the AD brain are neuronal and synapse loss, and the deposition of extracellular plaques composed of amyloid- $\beta$ (A $\beta$ ) peptides and intraneuronal neurofibrillary tangles consisting of hyperphosphorylated tau protein.

Although the most frequent form is sporadic $A D$, the rare autosomal and dominant early-onset form of $\mathrm{AD}$ 
(EOAD) has provided valuable insight into the disease pathogenesis.

Most dementia cases are late onset and are probably linked to both genetic and environmental factors. The most common risk factors include brain injury, diabetes, hypercholesterolemia and obesity. Moreover, recent studies seem to indicate an involvement of cerebrovascular risk factors in the development of a substantial proportion of dementia cases. With regard to the possible role of these risk factors in dementia, data (spanning 10 or 20 years) from large epidemiological studies conducted in Minnesota, Illinois and Indiana and from a US national study showed a substantial reduction in cognitive impairment in the general population, measured using neuropsychological tests, and thus justify cautious optimism over the possible impact of reducing cerebrovascular risk factors in dementia [2].

These data are also confirmed by the results of a Rotterdam study, which provided evidence of a reduction in the incidence of dementia between 1990 and 2005 [3].

Many experts agree that identifying AD early, before abnormal accumulation of amyloid and tau proteins, could provide an opportunity to hinder the progression of the disease.

A number of strategies under study were recently discussed at the 2012 annual meeting of the Society for Neuroscience. Several neuroimaging techniques have been included among the biomarkers of AD; however, scientific evidence is still under development [4].

To develop preventive treatments for AD, it is necessary to identify early biological markers that are predictive of AD. To date, the best-recognized in vivo markers are measures of brain structure and function, as obtained with neuroimaging. The distribution, in the brain, of the PET tracer $\left[{ }^{18} \mathrm{~F}\right] 2$-fluoro-2-deoxy-D-glucose (FDG) reflects regional glucose consumption, correlating with cerebral synaptic activity [5]. Since neurodegenerative dementias are characterized by synaptic and neuronal loss, FDG PET is able to consistently reveal significant hypometabolism in several cortical regions.

Brain volume loss as assessed on magnetic resonance imaging (MRI), and reductions in the cerebral metabolic rate of glucose (CMRglc) as measured with FDG PET are sensitive to AD-related brain changes. A crucial question is whether these brain measures can allow preclinical detection of dementia. To understand how AD starts and progresses, it is necessary to follow subjects through normal aging to the onset of clinical symptoms. Several studies have shown measures of brain atrophy directly assessed using MRI techniques, capable of capturing presymptomatic changes in familial forms of AD [6-8].

FDG PET studies have shown that decreased glucose metabolism in AD precedes clinical diagnosis and that the degree of clinical disability in AD correlates closely with the magnitude of the reduction in brain metabolism.

Recent studies have provided evidence of dynamic changes in PET amyloid and FDG imaging at different stages of $\mathrm{AD}$ [9]. In order to compare brain atrophy with hypometabolism as preclinical markers of $\mathrm{AD}$, several studies have presented data on presymptomatic mutation carriers from families with known early onset, autosomal dominant AD, i.e. familial AD (FAD) [10]. Presymptomatic FAD individuals have been found to show CMRglc reductions consistent with the expected AD PET pattern, but in the absence of severe atrophy on MRI [11]. These results suggest that PET CMRglc measures could potentially serve as preclinical biomarkers of dementia, useful also for tracking disease progression.

\section{New diagnostic criteria}

A few years ago, the results of many years of research allowed an update of the clinical research criteria for dementia and the refinement of guidelines (originally conceived around two and a half decades earlier) for diagnosis of the various forms of dementia [12]. Meanwhile, 2011 saw the publication of recommendations, from the National Institute on Aging-Alzheimer's Association workgroups, on diagnostic guidelines for Alzheimer's disease [13]. These new recommendations are the result of acquisitions obtained through both laboratory and clinical research.

The new criteria proposed a common lexicon for the clinical and research sectors [12], which has generated much debate in the scientific community [14-16]. Developments in the field of biomarkers and the use, alongside traditional genetics, of new more specific and more sensitive techniques were crucial for the development of these new criteria, but also for redefining frontotemporal dementia (FTD) and its subtypes.

Guidelines on the diagnosis and management of dementia disorders recently developed by a European Federation of Neurological Societies (EFNS) study group on dementia, which took into consideration the canonical syndromes and molecular genetic aspects, identify a number of different clinical forms of dementia with different ages at onset and/or durations [17].

Moreover, in accordance with recent EFNS-ENS guidelines on the use of neuroimaging in the diagnosis of dementia [18], structural imaging should be performed to exclude other potentially treatable diseases, to detect vascular lesions, and to identify specific findings to help distinguish between different forms of neurodegenerative dementia.

Neuroimaging is recommended in cases in which the diagnosis remains in doubt. Amyloid imaging is likely to 
prove clinically useful in several fields, including the evaluation of atypical AD presentations [18].

\section{Biomarkers}

Recent years have provided some important developments in the field of dementia, fundamental in furthering understanding of the pathogenetic mechanisms of the disease. It is now believed that AD pathophysiology started years before cognitive changes are detected and probably before the onset of clinical signs of dementia [19, 20]. Hence, there has emerged an urgent need for reliable diagnostic biomarkers able to detect the disease in a presymptomatic stage. Recent studies have focused on imaging markers or cerebrospinal fluid (CSF) and blood biomarkers for early diagnosis.

The biomarkers currently used for AD are both genetic, such as the pathogenetic mutations in three candidate genes (amyloid- $\beta$ precursor protein, APP; presenilin 1, PS1; presenilin 2, PS2) and biochemical (amyloid- $\beta$ and tau proteins in the CSF) [21]. Moreover, the biomarkers of neurodegeneration include neuroimaging correlates of hippocampal atrophy on structural MRI and symmetric decreased metabolism in the temporoparietal regions on FDG PET.

The ${ }^{11} \mathrm{C}$ Pittsburgh compound (PiB) has always been the most validated tracer for imaging amyloid pathology. However, there is now a new tracer, ${ }^{18} \mathrm{~F}$-florebetapir that, thanks to the longer half-life of the radioactive isotope ${ }^{18} \mathrm{~F}$ (110 versus $20 \mathrm{~min}$ for the ${ }^{11} \mathrm{C}$ of ${ }^{11} \mathrm{C}-\mathrm{PiB}$ ), has the potential to be used even more extensively both for clinical and research purposes [22].

In a 2003 study involving a family carrying the T122R mutation in PS2 and showing an atypical presentation of dementia, all the biomarkers (the functional neuroimaging investigations, CSF levels of $A \beta$ 1-42, and Tau protein) provided evidence indicating future dementia development [23].

Today, FDG PET has moved from the research arena into clinical practice. Amyloid imaging allows earlier diagnosis of $\mathrm{AD}$ and better differential diagnosis of dementia and it also provides prognostic information for mild cognitive impairment (MCI) [24].

\section{The genetics of dementia}

The genetic approach to the study of neurodegenerative diseases is undoubtedly the one that has provided and continues to provide the most significant contribution to understand the various aspects of these disorders: their pathogenesis and diagnosis, the therapeutic options, and the important ethical implications.
A search of the PubMed database using keywords such as "dementia" and "genetic" reveals, to date, more than 25,000 papers, almost half of which were published in the past 6 years. The earliest paper, published in 1952, concerns research into the genetics of AD and Pick's disease [25]; one of the most recent contributions is a large collaborative genome-wide association (GWA) study that highlights a new AD locus on chromosome 10 [26]. The list of genetic mutations associated with autosomal dominant forms of familial dementia is getting longer and longer [27].

The extensive study of the genetics of dementia led to the development of a molecular classification of different forms of dementia and now many groups are working to establish the possible diagnostic utility, in dementia, of the biological and genetic biomarkers developed [28].

\section{The genetics of $\mathrm{AD}$}

Alzheimer's disease is a genetically complex, multifactorial disease involving many candidate genes [29]. From a genetic point of view, AD can be divided into two different forms: FAD and sporadic AD. Apart from the fact that FAD often has onset at an earlier age and can present some neurological characteristics not generally present in the sporadic form, the two subtypes are clinically indistinguishable. AD can also be divided into two groups by age at onset: early onset (onset $<65$ years; EOAD) and late onset (onset $>65$ years; LOAD).

In rare early-onset FAD, different disease-causing mutations have been described. At the time of writing, the Alzheimer Disease \& Frontotemporal Dementia Mutation Database lists a total of 231 different fully penetrant autosomal dominant mutations in 517 families around the world (http://molgen-www.uia.ac.be/ADMutations/). These mutations are located in three genes (i.e. APP, PS1, $P S 2)$ that have been shown to cause $50 \%$ of all FAD. In particular, 33 pathogenetic mutations for APP, 185 for PS1 and 13 for $P S 2$ have been discovered [30, 31].

In the more common sporadic form, a locus on chromosome 19, coding for apolipoprotein E (ApoE), has been associated with increased susceptibility. In particular, genetic and epidemiological studies have identified the epsilon $4(\varepsilon 4)$ allele as a major risk factor for the disease, being associated with an increased risk of developing the disease and with a lower age at onset [32].

The ApoE $\varepsilon 4$ allele is the only confirmed factor involved in genetic susceptibility to $\mathrm{AD}$, but it is neither necessary nor sufficient to cause the disease [33]. Moreover, according to recent data, the ApoE could be a major gene with semi-dominant inheritance (individuals with a double dose of the $\varepsilon 4$ allele have a 35 -fold increased risk of developing the disease) [34]. 
The ApoE $\varepsilon 4$ isoform is thought to interact with the mechanisms associated with aging, resulting in deposition in the brain, of aggregated deposits of abnormal proteins; this impairs neurotransmission, thereby hastening the disease process [35, 36]. However, over $70 \%$ of all cases in the general population are associated with this gene, which suggests that numerous other factors, in addition to genetic predisposition, must together contribute to determining the disease [37].

In recent years, the search for other genetic factors has shown associations with polymorphisms in an increasing number of genes, all possibly involved, by interfering with the deposition and clearance of $A \beta$ in the disease pathogenesis [38].

Recent progress in genomic methodology and the availability of large sample sizes have ushered in the era of GWA studies.

From 2005 to the present, many GWA studies have been published and thanks to these studies; several loci associated with various neurodegenerative diseases have been identified.

According to the AlzGene database, GWA studies have identified ten novel loci associated with an increased risk of developing AD, i.e. BIN1, CLU, ABCA7, CR1, PICALM, MS4A6A, MS4A4E, CD33, CD2AP and EPHA1 [39-42].

The role of all the new genes in the pathogenesis of $\mathrm{AD}$ is supported by their involvement in the pathogenetic processes related to neurodegeneration, including the amyloidogenic cascade, tau hyperphosphorylation, apoptosis, oxidative stress, cholesterol and lipid metabolism, and immune inflammatory processes.

Despite these successes, this type of approach has many limitations because these associations do not have a high predictive value and may also lead to the identification of false positives and false negatives. For this type of approach, studying a very large number of subjects is necessary. In fact, whereas several thousand individuals are needed to describe an association with a rare, high-impact variant, the description of a common variant with a low effect requires many thousands of cases and controls [43].

For this purpose, international research groups have organized specific genetic consortia, thus making large collaborative studies feasible.

During 2011, thanks to a group of international researchers, the First International Collaboration on the Genetics of Alzheimer's Disease was established with a view to perform collaborative studies on large numbers of subjects (International Genomics of Alzheimer's Project).

Recent GWA studies have identified $C L U, C R 1, A B C A 7$ BINI, PICALM and MS4A6A/MS4A6E in addition to the long-established ApoE as loci for AD [39-42, 44].
New findings have recently provided fresh insight into the genetic mechanisms underlying the development of AD.

Starting from the hypothesis that low-prevalence variants showing moderate to high effect may be associated with AD risk, two independent research groups [45, 46] have shown that a rare variant (rs 75932628 encoding an arginine to histidine substitution at residue $47, \mathrm{R} 47 \mathrm{H}$ ) in the TREM2 gene, encoding the triggering receptor expressed on myeloid cells on chromosome 6 (6p21.1$\mathrm{q} 15$ ), is significantly associated with increased susceptibility to LOAD.

Another recent study has provided evidence that a lowfrequency variant of the coding mutation (A673T) in the $A P P$ gene protects against $\mathrm{AD}$ and cognitive decline in the elderly without AD $[47,48]$. The discovery of the protective effect of the A673T substitution against AD provides proof of the principle that reducing the $\beta$-cleavage of APP may protect against the disease, and supports the clinical usefulness of the current amyloid-directed therapeutic research efforts.

The recent important characterizations of the novel risk factor TREM2 and the novel protective APP-related variant displaying a statistically significant association with $\mathrm{AD}$ provide grounds for cautious optimism regarding the results of genetic research.

It has been suggested that families need clinical guidelines to help them navigate the complexities of dementia (in particular AD and FTD) genetics and the processes of genetic testing and counseling [49].

In fact, the diagnosis of progressive disease in a clinically healthy individual is a new but increasingly frequent scenario for the neurologists and geneticists [50], and it is one that carries ethical implications [51] and underlines the importance of genetic counseling. The genetic approach, being able to shed light on the pathogenetic mechanisms of the disease and thus indicate possible therapeutic avenues, is important both from a research and a clinical perspective. For example, a recent study aiming to investigate whether treatment with human anti-A $\beta$ monoclonal antibodies leads to a measurable reduction in the level of $A \beta$ in the brain and to elucidate the mechanism of amyloid reduction provided data on the use of an amyloid-eating drug that removes plaque through phagocytosis [52].

As pointed out by a recent editorial in Neurology [53], it is recommended to start treating patients before the disease becomes symptomatic, i.e. to exploit the window, in the preclinical stages of the disease, in which CSF and PET biomarkers correlated with amyloidogenic and neurodegenerative processes are significantly altered. 


\section{FDG PET and the genetics of AD}

The link between genetic susceptibility and AD could be elucidated by the association of AD candidate genes with alterations in brain functions, which can be assessed by FDG PET.

Several studies support the use of FDG PET as an AD biomarker and, furthermore, as an endophenotype for the assessment of genetic risk factors for AD.

FDG PET undoubtedly has many advantages; however, it could also have some limitations. First of all, metabolism studies are not able to provide information about the pathophysiological mechanisms linking genetic variability to $\mathrm{AD}$ susceptibility. In addition, CMRglc is also presumably subject to multiple genetic regulations and affected by environmental factors.

However, despite these limitations, FDG PET deserves to be considered a presymptomatic $\mathrm{AD}$ endophenotype, and several studies have already successfully used FDG PET to reveal CMRglc alterations in normal individuals who have a genetic risk of developing $\mathrm{AD}$.

\section{FDG PET and presymptomatic early-onset FAD}

Studies of individuals from families with FAD with known genetic mutations have provided unique information about preclinical AD-related brain impairment and they constitute an ideal resource for exploring the relationship between genetic and phenotypic expression of the disease. Several FDG PET studies on presymptomatic FAD subjects showed the presence of regional parieto-temporal, posterior cingulate cortex (PCC) and medial temporal lobe hypometabolism on a background of wide-spread global CMRglc impairment (Fig. 1) [11, 54, 55].

In particular, a previous FDG PET study on presymptomatic at-risk individuals carrying the rare APP mutations (compared to individuals without mutations) reported the presence of parieto-temporal hypometabolism, with additional frontal deficits [56]. Similarly, a recent FDG PET study conducted on carriers of the PS2 mutation demonstrated CMRglc reductions in parietal and precuneus regions, showing progression at follow-up in parieto-temporal and frontal lobes [57].

Interestingly, an FDG PET study of presymptomatic PS1 mutation carriers provided definitive evidence that CMRglc reductions precede not only clinical symptoms but also structural brain changes, showing cortical and medial temporal lobe metabolic reductions, occurring before and exceeding structural brain atrophy observed on MRI. After partial volume correction, CMRglc reductions ranged from $13 \%$ (whole brain) to $21 \%$ (PCC), reflecting true reductions in brain glucose utilization per unit brain volume; after partial volume correction, the medial temporal lobe
CMRglc values were reduced to $12 \%$ in the hippocampus and $20 \%$ in the entorhinal cortex [11].

These findings are consistent with and could be explained by the $\mathrm{AD}$ pathological cascade model: following the initial deposition of amyloid plaques, the dominant process is represented by neuronal and synaptic dysfunction, which could be studied using FDG PET. The neuronal loss that ultimately causes atrophy measurable with MRI appears only later [58].

\section{FDG PET and ApoE-associated genetic risk}

The $\varepsilon 4$ allele of the ApoE gene is a widely recognized genetic risk factor for $\mathrm{AD}$ and the association between the ApoE $\varepsilon 4$ allele and $\mathrm{AD}$ risk has been reported in hundreds of studies. The ApoE $\varepsilon 4$ genotype is considered a risk factor since almost $40 \%$ of LOAD patients have at least one ApoE $\varepsilon 4$ allele; moreover, a copy of the $\varepsilon 4$ allele is found in about $25 \%$ of Americans and in $33 \%$ of those with a reported family history of dementia in a first-degree relative. Two copies of the $\varepsilon 4$ allele are found in 2-3\% of Americans and about $5 \%$ of those with a reported history of dementia in a first-degree relative [59].

To date, many FDG PET studies have been published, examining the effect of the presence of the ApoE $\varepsilon 4$ allele on CMRglc and confirming, study after study, the association between metabolic impairment, assessed by FDG PET, and AD genetic risk factors in cognitively normal subjects. FDG PET studies in non-demented individuals report that, as compared to $\varepsilon 4$ non-carriers, ApoE $\varepsilon 4$ homozygotes (therefore, with a particularly high risk of developing $\mathrm{AD}$ ) have a significantly reduced CMRglc in the same brain regions as clinically affected AD patients, including the posterior cingulate/precuneus, parietal, temporal and prefrontal regions [59]. As compared to $\varepsilon 4$ noncarriers, ApoE $\varepsilon 4$ heterozygotes show similar, but milder, hypometabolism within the same brain regions found to be affected in $\mathrm{AD}$ patients and in ApoE $\varepsilon 4$ homozygotes [5962]. There is evidence that the metabolic reductions in ApoE $\varepsilon 4$ carriers are more progressive $(25 \%$ decline in CMRglc over a two-year interval) and correlate with the reductions in cognitive performance [63].

Moreover, CMRglc abnormalities have been detected even earlier, in 20- to 40-year-old ApoE $\varepsilon 4$ carriers [64], making them the earliest brain abnormalities yet found in living subjects at risk of $\mathrm{AD}$, detected many years before the estimated median age of dementia onset in $\varepsilon 4$ heterozygotes.

The ApoE $\varepsilon 4$ allele also contributes to heterogeneity in MCI patients by regionally affecting brain metabolic activity, so that MCI ApoE $\varepsilon 4$ carriers present a more extensive CMRglc impairment than non-carriers, reflecting the known ApoE \&4-related increased vulnerability to 
Fig. 1 FDG PET scans (first row) and MRI co-registration of two preclinical early-onset FAD siblings with the APP 717 ValIle mutation. Case 1 a 60 -yearold male with deficits in shortand long-term memory and in visuospatial and executive functions showed mild parietal and hippocampal atrophy associated with severe parietal hypometabolism and moderate CMRglc reductions in the frontal cortex and hippocampus. Case 2 a 48-year-old female showed only long-term memory deficits and no significant atrophy on the MRI scan. However, the FDG PET scan demonstrated the presence of mild parietal and inferior frontal hypometabolism (arrows indicate the hypometabolism)
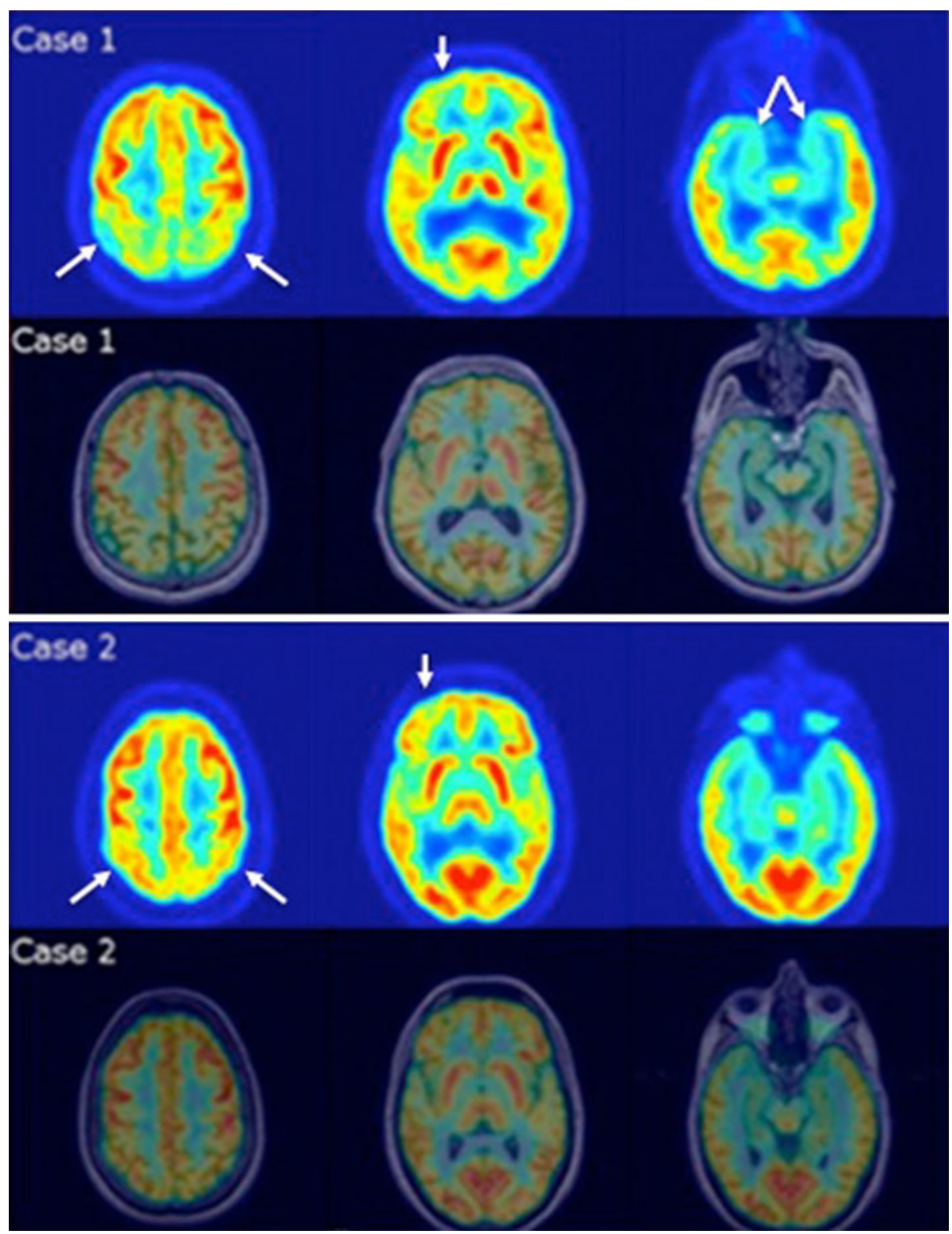

dementia [65]. In particular, the hypometabolism usually found in parietotemporal and temporal regions in MCI patients extended to the frontal and anterior cingulate cortex in MCI ApoE $\varepsilon 4$ carriers. A recent study showed a differential effect of ApoE genotype on amyloid load and glucose metabolism in $\mathrm{AD}$ patients [66], confirming earlier reports.

FDG PET and maternal family history of AD

FDG PET studies have also proved to be useful in estimating the increased risk of future $\mathrm{AD}$ in another cognitively normal at-risk population, namely subjects with a maternal family history of AD. Indeed, recent reports provided evidence for phenotypic CMRglc differences between cognitively normal individuals with a maternal, paternal or negative family history of $\mathrm{AD}$ [67], even preceding the structural brain abnormalities observed on MRI [68]. In particular, individuals with a maternal history of $\mathrm{AD}$ were found to show CMRglc reductions in typically AD-vulnerable brain regions, namely the parietotemporal, posterior cingulate/precuneus, medial temporal and prefrontal cortices, as compared to individuals with no family history and those with an AD-affected father [67]. The hypometabolism occurred within the group of maternal $\mathrm{AD}$ subjects independently of the subject's age, gender, years of education and ApoE genotype.

Over a two-year follow-up, CMRglc impairment in maternal AD individuals was found to be progressive [69], with longitudinal CMRglc reductions in the posterior cingulate/precuneus, parietotemporal and frontal cortices. In contrast, individuals with an AD-affected father and those 
with no family history of AD showed longitudinal CMRglc reductions only in the frontal cortex, which is a typical effect of aging.

\section{FDG PET and the KIBRA gene}

KIBRA is a cytoplasmic protein that is highly expressed in the brain and is a binding partner of dendrin, a putative modulator of synaptic plasticity. There are two allelic variants of the KIBRA gene ( $\mathrm{T}$ and $\mathrm{C}$ ), resulting in three possible genotypes: TT, CT and CC. GWA studies and several replication studies $[70,71]$ demonstrated that $K I$ $B R A \mathrm{~T}$ allele non-carriers (CC genotype) had lower episodic memory performance compared to KIBRA T carriers (CT and TT genotypes).

Since memory impairment is the cardinal clinical feature of $\mathrm{AD}$, the next step was to investigate the possibility of an association between AD and KIBRA. Corneveaux and colleagues [72] tested this hypothesis using data from FDG PET, as an endophenotype. KIBRA T non-carriers showed significant CMRglc reductions, compared to KIBRA T carriers, in the same brain regions preferentially affected by $\mathrm{AD}$, including the precuneus and PCC.

These FDG PET findings provide a foundation for a common molecular mechanism contributing not only to successful episodic memory performance but also to the predisposition to $\mathrm{AD}$, opening possible future perspectives for memory-enhancing, $\mathrm{AD}$-modifying and $\mathrm{AD}$ riskreducing therapies.

\section{Genetics of FTD}

First described over 100 years ago, today we can refer to several clinical forms and at least 16 different pathological subtypes of FTD [73].

FTD refers to a disease spectrum including the behavioral variant FTD (bvFTD), primary progressive aphasia (PPA), progressive supranuclear palsy/corticobasal degeneration syndrome (PSP/CBDS), and FTD with amyotrophic lateral sclerosis (FTD-ALS).

The international consortia for the two main syndromes, bvFTD and PPA, have recently revised the diagnostic criteria and published consensus criteria [74, 75], including neuroimaging and genetics.

The first evidence of a genetic cause of familial FTD was provided 18 years ago with the demonstration of a linkage to chromosome 17 in a familial form with autosomal dominant parkinsonism [76]; the most recent evidence is a GGGGCC expansion in $C 9$ orf72, a major cause of FTD and ALS [77, 78].

To date, the familial forms of FTD [79] are explained by the seven genes (C9orf72, CHMP2B, FUS, GRN, MAPT,
TARDBP, $V C P$ ), in which 193 pathogenetic mutations have been described (http://www.molgen.ua.ac.be/ADMutations). All the genes code for a protein including C9orf72 [80], an open reading frame coding for a protein recently characterized and located on chromosome 9p21 [77, 78, 80]. The most revolutionary finding on the genetics of FTD is that these mutations and expansions concern a very high percentage of families in the world. Indeed, there are now more than 900 families in the world with mutations associated with FTD. A flow chart for FTD genetic testing was recently published [81].

There also exist phenotypic characterizations of FTD linked to the mutations in $G R N$ and $C 9$ orf72 and in which an important contribution is made by neuroimaging [82]. In particular, a study in monozygotic twins carrying a 4-bp deletion (c.388_391delCAGT) in exon 4 of GRN reported strong clinical, neuroimaging, and serum progranulin level similarities, demonstrating the importance of shared genetic profiles beyond environmental influences in the symptomatic expression of the disease [82]. In a recent case report, brain FDG PET demonstrated mild hypometabolism involving the medial frontal and lateral temporal lobes, the left more than the right, which progressed over time. This case was subsequently confirmed to have the C9orf72 expansion, thus highlighting the need to consider mutations in the FTD-associated genes when a familial disorder is suggested and neuroimaging studies reveal findings atypical of an $\mathrm{AD}$ pathophysiological process, despite the typical anterograde amnesic syndrome [83].

Different research centers worldwide are involved in the genetic approach to FTD. The work of GENFI (http://www.ucl.ac.uk/drc/research/current-studies/genfi), a multicenter collaborative consortium for tracking the evolution of genetic FTD and its associated disorders from their earliest stages, is ongoing.

The main aim of GENFI is to recruit and follow a wellcharacterized and uniformly studied cohort of individuals affected with or at risk of developing the major genetic forms of FTD with mutations in the MAPT or GRN genes or expansions in the C9orf72 gene.

The innovative aim of the consortium is to derive sample size estimates and outcome measures for future natural history studies and clinical trials of disease-modifying therapies.

\section{Conclusions}

Several studies describe the contribution made by FDG PET and genetics to understand the pathogenesis of dementia. The reported data on presymptomatic mutation carriers from families with known early-onset autosomal dominant $\mathrm{AD}$ (FAD) show reductions in the cerebral 
glucose metabolism consistent with the typical AD PET pattern.

These reported results indicate that PET brain metabolic measures have a potential role to play as preclinical biomarkers for genetic dementia and for tracking disease progression.

Acknowledgments This study was supported by grants from the Cassa di Risparmio di Pistoia e Pescia (Grant 2012) and the Cassa di Risparmio di Firenze (Grant 2012).

Conflict of interest B. Nacmias, V. Berti, I. Piaceri, S. Sorbi declare that they have no conflict of interest.

Human and Animal Studies This article does not contain any studies with human or animal subjects performed by any of the authors.

\section{References}

1. Ballard C, Gauthier S, Corbett A, Brayne C, Aarsland D, Jones E (2011) Alzheimer's disease. Lancet 377(9770):1019-1031. doi: 10.1016/S0140-6736(10)61349-9

2. Rocca WA, Petersen RC, Knopman DS, Hebert LE, Evans DA, Hall KS, Gao S, Unverzagt FW, Langa KM, Larson EB, White LR (2011) Trends in the incidence and prevalence of Alzheimer's disease, dementia, and cognitive impairment in the United States. Alzheimers Dement 7(1):80-93. doi:10.1016/j.jalz.2010.11.002

3. Schrijvers EM, Verhaaren BF, Koudstaal PJ, Hofman A, Ikram MA, Breteler MM (2012) Is dementia incidence declining?: trends in dementia incidence since 1990 in the Rotterdam Study. Neurology 78(19):1456-1463. doi:10.1212/WNL.0b013e31825 53be6

4. Friedrich MJ (2013) Studies suggest potential approaches for early detection of Alzheimer disease. JAMA 309(1):18-19. doi: 10.1001/jama.2012.105106

5. Pellerin L, Magistretti PJ (2012) Sweet sixteen for ANLS. J Cereb Blood Flow Metab 32(7):1152-1166. doi:10.1038/jcbfm. 2011.149

6. Ridha BH, Barnes J, Bartlett JW, Godbolt A, Pepple T, Rossor MN, Fox NC (2006) Tracking atrophy progression in familial Alzheimer's disease: a serial MRI study. Lancet Neurol 5(10): 828-834. doi:10.1016/S1474-4422(06)70550-6

7. Knight WD, Kim LG, Douiri A, Frost C, Rossor MN, FoxNC (2009) Acceleration of cortical thinning in familial Alzheimer's disease. Neurobiol Aging 32(10):1765-73. doi:10.1016/j.neuro biolaging.2009.11.013

8. Lee GJ, Lu PH, Medina LD, Rodriguez-Agudelo Y, Melchor S, Coppola G, Braskie MN, Hua X, Apostolova LG, Leow AD, Thompson PM, Ringman JM (2013) Regional brain volume differences in symptomatic and presymptomatic carriers of familial Alzheimer's disease mutations. J Neurol Neurosurg Psychiatry 84(2):154-162. doi:10.1136/jnnp-2011-302087

9. Kadir A, Almkvist O, Forsberg A, Wall A, Engler H, Långström B, Nordberg A (2012) Dynamic changes in PET amyloid and FDG imaging at different stages of Alzheimer's disease. Neurobiol Aging 33(1):198.e1-14. doi:10.1016/j.neurobiolaging.2010.06.015

10. Kennedy AM, Frackowiak RS, Newman SK, Bloomfield PM, Seaward J, Roques P, Lewington G, Cunningham VJ, Rossor MN (1995) Deficits in cerebral glucose metabolism demonstrated by positron emission tomography in individuals at risk of familial
Alzheimer's disease. Neurosci Lett 186:17-20. doi:10.1016/ 0304-3940(95)11270-7

11. Mosconi L, Sorbi S, de Leon MJ, Li Y, Nacmias B, Myoung PS, Tsui W, Ginestroni A, Bessi V, Fayyazz M, Caffarra P, Pupi A (2006) Hypometabolism exceeds atrophy in presymptomatic early-onset familial Alzheimer's disease. J Nucl Med 47:1778-1786

12. Dubois B, Feldman HH, Jacova C, Cummings JL, Dekosky ST, Barberger-Gateau P, Delacourte A, Frisoni G, Fox NC, Galasko D, Gauthier S, Hampel H, Jicha GA, Meguro K, O'Brien J, Pasquier F, Robert P, Rossor M, Salloway S, Sarazin M, de Souza LC, Stern Y, Visser PJ, Scheltens P (2010) Revising the definition of Alzheimer's disease: a new lexicon. Lancet Neurol 9(11):1118-1127. doi:10.1016/S1474-4422(10)70223-4

13. McKhann GM, Knopman DS, Chertkow H, Hyman BT, Jack CR Jr, Kawas CH, Klunk WE, Koroshetz WJ, Manly JJ, Mayeux R, Mohs RC, Morris JC, Rossor MN, Scheltens P, Carrillo MC, Thies B, Weintraub S, Phelps CH (2011) The diagnosis of dementia due to Alzheimer's disease: recommendations from the National Institute on Aging-Alzheimer's Association workgroups on diagnostic guidelines for Alzheimer's disease. Alzheimers Dement 7(3):263-269. doi:10.1016/j.jalz.2011.03.005

14. Musicco M, Padovani A, Sorbi S, Scarpini E, Caffarra P, Cappa S, Clerici F, Tabaton M, Caltagirone C, Bonavita V, Bruni AC, Bruno G, Federico A, Ferrarese C, Marra C, Nacmias B, Parnetti L, Pettenati C, Sorrentino G, Tagliavini F, Mariani C (2012) Position paper of the Italian Society for the study of Dementias (SINDEM) on the proposal of a new lexicon on Alzheimer disease. Neurol Sci 33(1):201-208. doi:10.1007/s10072-011-0825-8

15. Sohrabi HR, Weinborn M, Badcock J, Bates KA, Clarnette R, Trivedi D, Verdile G, Sutton T, Lenzo NP, Gandy SE, Martins RN (2011) New lexicon and criteria for the diagnosis of Alzheimer's disease. Lancet Neurol 10(4):299-300. doi: 10.1016/S1474-4422(11)70056-4

16. Giaccone G, Arzberger T, Alafuzoff I, Al-Sarraj S, Budka H, Duyckaerts C, Falkai P, Ferrer I, Ironside JW, Kovács GG, Meyronet D, Parchi P, Patsouris E, Revesz T, Riederer P, Rozemuller A, Schmitt A, Winblad B, Kretzschmar H; BrainNet Europe consortium (2011) New lexicon and criteria for the diagnosis of Alzheimer's disease. Lancet Neurol 10(4):298-299. doi:10.1016/S1474-4422(11)70055-2

17. Sorbi S, Hort J, Erkinjuntti T, Fladby T, Gainotti G, Gurvit H, Nacmias B, Pasquier F, Popescu BO, Rektorova I, Religa D, Rusina R, Rossor M, Schmidt R,Stefanova E, Warren JD, Scheltens P; EFNS Scientist Panel on Dementia and Cognitive Neurology (2012) EFNS-ENS Guidelines on the diagnosis and management of disorders associated with dementia. Eur J Neurol 19(9):1159-1179. doi:10.1111/j.1468-1331.2012.03784.x

18. Filippi M, Agosta F, Barkhof F, Dubois B, Fox NC, Frisoni GB, Jack CR, Johannsen P, Miller BL, Nestor PJ, Scheltens P, Sorbi S, Teipel S, Thompson PM, Wahlund LO (2012). EFNS task force: the use of neuroimaging in the diagnosis of dementia. Eur $\mathbf{J}$ Neurol 19(12):e131-40, 1487-501. doi:10.1111/j.1468-1331. 2012.03859.x

19. Fratiglioni L, Wang HX (2007) Brain reserve hypothesis in dementia. J Alzheimers Dis 12:11-22

20. Roe CM, Rentz DM (2013) Alzheimer disease: before the diagnosis. Neurology 80(13):e148-e149. doi:10.1212/WNL.0b013e 31828 cade 3

21. Mandal PK (2012) Predictive biomarkers for Alzheimer's disease using state-of-the-art brain imaging techniques. J Alzheimers Dis 31(Suppl):S1-3

22. Jack CR Jr (2012) Alzheimer's disease: new concepts on its neurobiology and the clinical role imaging will play. Radiology 263:344-361. doi:10.1148/radiol.12110433 
23. Binetti G, Signorini S, Squitti R, Alberici A, Benussi L, Cassetta E, Frisoni GB, Barbiero L, Feudatari E, Nicosia F, Testa C, Zanetti O, Gennarelli M, Perani D, Anchisi D, Ghidoni R, Rossini PM (2003) Atypical dementia associated with a novel presenilin2 mutation. Ann Neurol 54(6):832-836. doi:10.1002/ana.10760

24. Rowe CC, Villemagne VL (2013) Amyloid imaging with PET in early Alzheimer disease diagnosis. Med Clin North Am 97(3):377-398. doi:10.1016/j.mcna.2012.12.017

25. Sjogren T, Sjogren H, Lindgren AG (1952) Morbus Alzheimer and morbus Pick; a genetic, clinical and patho-anatomical study. Acta Psychiatr Neurol Scand Suppl 82:1-152

26. Lambert JC, Lambert JC, Grenier-Boley B, Harold D, Zelenika D, Chouraki V, Kamatani Y, Sleegers K, Ikram MA, Hiltunen M, Reitz C, Mateo I, Feulner T, Bullido M, Galimberti D, Concari L, Alvarez V, Sims R, Gerrish A, Chapman J, DenizNaranjo C, Solfrizzi V, Sorbi S, Arosio B, Spalletta G, Siciliano G, Epelbaum J, Hannequin D, Dartigues JF, Tzourio C, Berr C, Schrijvers EM, Rogers R, Tosto G, Pasquier F, Bettens $\mathrm{K}$, Van Cauwenberghe C, Fratiglioni L, Graff C, Delepine M, Ferri R, Reynolds CA, Lannfelt L, Ingelsson M, Prince JA, Chillotti C, Pilotto A, Seripa D, Boland A, Mancuso M, Bossù P, Annoni G, Nacmias B, Bosco P, Panza F, Sanchez-Garcia F, Del Zompo M, Coto E, Owen M, O'Donovan M, Valdivieso F, Zaffara P, Scarpini E, Combarros O, Buée L, Campion D, Soininen H, Breteler M, Riemenschneider M, Van Broeckhoven C, Alpérovitch A, Lathrop M, Trégouët DA, Williams J, Amouyel P (2013) Genome-wide haplotype association study identifies the FRMD4A gene as a risk locus for Alzheimer's disease. Mol Psychiatry 18(4):461-470. doi:10.1038/mp. 2012.14

27. Rossor MN, Fox NC, Mummery CJ, Schott JM, Warren JD (2010) The diagnosis of young-onset dementia. Lancet Neurol 9(8):793-806. doi:10.1016/S1474-4422(10)70159-9

28. Honig LS (2012) Translational research in neurology: dementia. Arch Neurol 69(8):969-977. doi:10.1001/archneurol.2011.2883

29. Piaceri I, Nacmias B, Sorbi S (2013) Genetics of familial and sporadic Alzheimer's disease. Front Biosci (Elite Ed) 5:167-177

30. Goate A, Chartier-Harlin MC, Mullan M, Brown J, Crawford F, Fidani L, Giuffra L, Haynes A, Irving N, James L et al (1991) Segregation of a missense mutation in the amyloid precursor protein gene with familial Alzheimer's disease. Nature 349:704706. doi: $10.1038 / 349704 \mathrm{a} 0$

31. Goate A, Hardy J (2012) Twenty years of Alzheimer's diseasecausing mutations. J Neurochem 120(Suppl 1):3-8. doi:10.1111/j. 1471-4159.2011.07575.x

32. Corder EH, Saunders AM, Strittmatter WJ, Schmechel DE, Gaskell PC, Small GW, Roses AD, Haines JL, Pericak-Vance MA (1993) Gene dose of apolipoprotein E type 4 allele and the role of Alzheimer's disease in late onset families. Science 261:921-923. doi:10.1126/science. 8346443

33. Strittmatter WJ, Roses AD (1995) Apolipoprotein E and Alzheimer disease. Proc Natl Acad Sci USA 92(11):4725-4727. doi: 10.1073/pnas.92.11.4725

34. Genin E, Hannequin D, Wallon D, Sleegers K, Hiltunen M, Combarros O, Bullido MJ, Engelborghs S, De Deyn P, Berr C, Pasquier F, Dubois B, Tognoni G, Fiévet N, Brouwers N, Bettens K, Arosio B, Coto E, Del Zompo M, Mateo I, Epelbaum J, FrankGarcia A, Helisalmi S, Porcellini E, Pilotto A, Forti P, Ferri R, Scarpini E, Siciliano G, Solfrizzi V, Sorbi S, Spalletta G, Valdivieso F, Vepsäläinen $S$, Alvarez V, Bosco P, Mancuso M, Panza F, Nacmias B, Bossù P, Hanon O, Piccardi P, Annoni G, Seripa D, Galimberti D, Licastro F, Soininen H, Dartigues JF, Kamboh MI, Van Broeckhoven C, Lambert JC, Amouyel P, Campion D (2011) APOE and Alzheimer disease: a major gene with semi-dominant inheritance. Mol Psychiatry 16(9):903-907. doi:10.1038/mp.2011.52
35. Mesulam MM (1999) Neuroplasticity failure in Alzheimer's disease: bridging the gap between plaques and tangles. Neuron 24(3):521-529. doi:10.1016/S0896-6273(00)81109-5

36. Isacson O, Seo H, Lin L, Albeck D, Granholm AC (2002) Alzheimer's disease and Down's syndrome: roles of APP, trophic factors and ACh. Trends Neurosci 25(2):79-84. doi: $10.1016 / \mathrm{S} 0166-2236(02) 02037-4$

37. Mill J (2011) Toward an integrated genetic and epigenetic approach to Alzheimer's disease. Neurobiol Aging 32(7):1188-1191. doi:10.1016/j.neurobiolaging.2010.10.021

38. Moraes CF, Lins TC, Carmargos EF, Naves JO, Pereira RW, Nóbrega OT (2012) Lessons from genome-wide association studies findings in Alzheimer's disease. Psychogeriatrics 12(1):62-73. doi:10.1111/j.1479-8301.2011.00378.x

39. Lambert JC, Heath S, Even G, Campion D, Sleegers K, Hiltunen M, Combarros O, Zelenika D, Bullido MJ, Tavernier B, Letenneur L, Bettens K, Berr C, Pasquier F, Fiévet N, BarbergerGateau P, Engelborghs S, De Deyn P, Mateo I, Franck A, Helisalmi S, Porcellini E, Hanon O; European Alzheimer's Disease Iniziative Investigators, de Pancorbo MM, Lendon C, Dufouil C, Jaillard C, Leveillard T, Alvarez V, Bosco P, Mancuso M, Panza F, Nacmias B, Bossù P, Piccardi P, Annoni G, Seripa D, Galimberti D, Hannequin D, Licastro F, Soininen H, Ritchie K, Blanché H, Dartigues JF, Tzourio C, Gut I, Van Broeckhoven C, Alpérovitch A, Lathrop M, Amouyel P (2009) Genome-wide association study identifies variants at CLU and CR1 associated with Alzheimer's disease. Nat Genet 41(10):1094-1099. doi: 10.1038/ng.439

40. Harold D, Abraham R, Hollingworth P, Sims R, Gerrish A, Hamshere ML, Pahwa JS, Moskvina V, Dowzell K, Williams A, Jones N, Thomas C, Stretton A, Morgan AR, Lovestone S, Powell J, Proitsi P, Lupton MK, Brayne C, Rubinsztein DC, Gill M, Lawlor B, Lynch A, Morgan K, Brown KS, Passmore PA, Craig D, McGuinness B, Todd S, Holmes C, Mann D, Smith AD, Love S, Kehoe PG, Hardy J, Mead S, Fox N, Rossor M, Collinge J, Maier W, Jessen F, Schürmann B, van den Bussche H, Heuser I, Kornhuber J, Wiltfang J, Dichgans M, Frölich L, Hampel H, Hüll M, Rujescu D, Goate AM, Kauwe JS, Cruchaga C, Nowotny P, Morris JC, Mayo K, Sleegers K, Bettens K, Engelborghs S, De Deyn PP, Van Broeckhoven C, Livingston G, Bass NJ, Gurling H, McQuillin A, Gwilliam R, Deloukas P, Al-Chalabi A, Shaw CE, Tsolaki M, Singleton AB, Guerreiro R, Mühleisen TW, Nöthen MM, Moebus S, Jöckel KH, Klopp N, Wichmann HE, Carrasquillo MM, Pankratz VS, Younkin SG, Holmans PA, O'Donovan M, Owen MJ, Williams J (2009) Genome-wide association study identifies variants at CLU and PICALM associated with Alzheimer's disease. Nat Genet 41:1088-1093. doi: 10.1038/ng.440

41. Naj AC, Jun G, Beecham GW, Wang LS, Vardarajan BN, Buros J, Gallins PJ, Buxbaum JD, Jarvik GP, Crane PK, Larson EB, Bird TD, Boeve BF, Graff-Radford NR, De Jager PL, Evans D, Schneider JA, Carrasquillo MM, Ertekin-Taner N, Younkin SG, Cruchaga C, Kauwe JS, Nowotny P, Kramer P, Hardy J, Huentelman MJ, Myers AJ, Barmada MM, Demirci FY, Baldwin CT, Green RC, Rogaeva E, St George-Hyslop P, Arnold SE, Barber R, Beach T, Bigio EH, Bowen JD, Boxer A, Burke JR, Cairns NJ, Carlson CS, Carney RM, Carroll SL, Chui HC, Clark DG, Corneveaux J, Cotman CW, Cummings JL, DeCarli C, DeKosky ST, Diaz-Arrastia R, Dick M, Dickson DW, Ellis WG, Faber KM, Fallon KB, Farlow MR, Ferris S, Frosch MP, Galasko DR, Ganguli M, Gearing M, Geschwind DH, Ghetti B, Gilbert JR, Gilman S, Giordani B, Glass JD, Growdon JH, Hamilton RL, Harrell LE, Head E, Honig LS, Hulette CM, Hyman BT, Jicha GA, Jin LW, Johnson N, Karlawish J, Karydas A, Kaye JA, Kim R, Koo EH, Kowall NW, Lah JJ, Levey AI, Lieberman AP, Lopez OL, Mack WJ, Marson DC, Martiniuk F, Mash DC, 
Masliah E, McCormick WC, McCurry SM, McDavid AN, McKee AC, Mesulam M, Miller BL, Miller CA, Miller JW, Parisi JE, Perl DP, Peskind E, Petersen RC, Poon WW, Quinn JF, Rajbhandary RA, Raskind M, Reisberg B, Ringman JM, Roberson ED, Rosenberg RN, Sano M, Schneider LS, Seeley W, Shelanski ML, Slifer MA, Smith CD, Sonnen JA, Spina S, Stern RA, Tanzi RE, Trojanowski JQ, Troncoso JC, Van Deerlin VM, Vinters HV, Vonsattel JP, Weintraub S, Welsh-Bohmer KA, Williamson J, Woltjer RL, Cantwell LB, Dombroski BA, Beekly D, Lunetta KL, Martin ER, Kamboh MI, Saykin AJ, Reiman EM, Bennett DA, Morris JC, Montine TJ, Goate AM, Blacker D, Tsuang DW, Hakonarson H, Kukull WA, Foroud TM, Haines JL, Mayeux R, Pericak-Vance MA, Farrer LA, Schellenberg GD (2011) Common variants at MS4A4/MS4A6E, CD2AP, CD33 and EPHA1 are associated with late-onset Alzheimer's disease. Nat Genet 43:436-441. doi:10.1038/ng.801

42. Hollingworth P, Harold D, Sims R, Gerrish A, Lambert JC, Carrasquillo MM, Abraham R, Hamshere ML, Pahwa JS, Moskvina V, Dowzell K, Jones N, Stretton A, Thomas C, Richards A, Ivanov D, Widdowson C, Chapman J, Lovestone S, Powell J, Proitsi P, Lupton MK, Brayne C, Rubinsztein DC, Gill M, Lawlor B, Lynch A, Brown KS, Passmore PA, Craig D, McGuinness B, Todd S, Holmes C, Mann D, Smith AD, Beaumont H, Warden D, Wilcock G, Love S, Kehoe PG, Hooper NM, Vardy ER, Hardy J, Mead S, Fox NC, Rossor M, Collinge J, Maier W, Jessen F, Rüther E, Schürmann B, Heun R, Kölsch H, van den Bussche H, Heuser I, Kornhuber J, Wiltfang J, Dichgans M, Frölich L, Hampel H, Gallacher J, Hüll M, Rujescu D, Giegling I, Goate AM, Kauwe JS, Cruchaga C, Nowotny P, Morris JC, Mayo K, Sleegers K, Bettens K, Engelborghs S, De Deyn PP, Van Broeckhoven C, Livingston G, Bass NJ, Gurling $\mathrm{H}$, McQuillin A, Gwilliam R, Deloukas P, Al-Chalabi A, Shaw CE, Tsolaki M, Singleton AB, Guerreiro R, Mühleisen TW, Nöthen MM, Moebus S, Jöckel KH, Klopp N, Wichmann HE, Pankratz VS, Sando SB, Aasly JO, Barcikowska M, Wszolek ZK, Dickson DW, Graff-Radford NR, Petersen RC; Alzheimer's Disease Neuroimaging Initiative, van Duijn CM, Breteler MM, Ikram MA, DeStefano AL, Fitzpatrick AL, Lopez O, Launer LJ, Seshadri S; CHARGE consortium, Berr C, Campion D, Epelbaum J, Dartigues JF, Tzourio C, Alpérovitch A, Lathrop M; EADI1 consortium, Feulner TM, Friedrich P, Riehle C, Krawczak M, Schreiber S, Mayhaus M, Nicolhaus S, Wagenpfeil S, Steinberg S, Stefansson H, Stefansson K, Snaedal J, Björnsson S, Jonsson PV, Chouraki V, Genier-Boley B, Hiltunen M, Soininen H, Combarros O, Zelenika D, Delepine M, Bullido MJ, Pasquier F, Mateo I, Frank-Garcia A, Porcellini E, Hanon O, Coto E, Alvarez V, Bosco P, Siciliano G, Mancuso M, Panza F, Solfrizzi V, Nacmias B, Sorbi S, Bossù P, Piccardi P, Arosio B, Annoni G, Seripa D, Pilotto A, Scarpini E, Galimberti D, Brice A, Hannequin D, Licastro F, Jones L, Holmans PA, Jonsson T, Riemenschneider M, Morgan K, Younkin SG, Owen MJ, O’Donovan M, Amouyel P, Williams J (2011) Common variants at ABCA7, MS4A6A/MS4A4E, EPHA1, CD33 and CD2AP are associated with Alzheimer's disease. Nat Genet 43:429-435. doi:10.1038/ ng.803

43. Pawitan Y, Seng KC, Magnusson PK (2009) How many genetic variants remain to be discovered? PLoS ONE 4(12):e7969. doi: 10.1371/journal.pone.0007969

44. Holton P, Ryten M, Nalls M, Trabzuni D, Weale ME, Hernandez D, Crehan H, Gibbs JR, Mayeux R, Haines JL, Farrer LA, Pericak-Vance MA, Schellenberg GD; Alzheimer's Disease Genetics Consortium, Ramirez-Restrepo M, Engel A, Myers AJ, Corneveaux JJ, Huentelman MJ, Dillman A, Cookson MR, Reiman EM, Singleton A, Hardy J, Guerreiro R, Apostolova LG, Arnold SE, Baldwin CT, Barber R, Barmada MM Beach TG, Beecham GW, Beekly D, Bennett DA, Bigio EH, Bird TD,
Blacker D, Boeve BF, Bowen JD, Boxer A, Burke JR, Buros J, Buxbaum JD, Cairns NJ, Cantwell LB, Cao C, Carlson CS, Carney RM, Carrasquillo MM, Carroll SL, Chui HC, Clark DG, Cotman CW, Crane PK, Crocco EA, Cruchaga C, Cummings JL, De Jager PL, DeCarli C, DeKosky ST, Demirci FY, Diaz-Arrastia R, Dick M, Dickson DW, Duara R, Ellis WG, Ertekin-Taner N, Evans D, Faber KM, Fallon KB, Farlow MR, Ferris S, Foroud TM, Frosch MP, Galasko DR, Ganguli M, Gearing M, Geschwind DH, Ghetti B, Gilbert JR, Gilman S, Giordani B, Glass JD, Goate AM, Graff-Radford NR, Green RC, Growdon JH, Hakonarson H, Hamilton RL, Harrell LE, Head E, Honig LS, Hulette CM, Hyman BT, Jarvik GP, Jicha GA, Jin LW, Jun G, Kamboh MI, Karlawish J, Karydas A, Kauwe JS, Kaye JA, Kim R, Koo EH, Kowall NW, Kramer P, Kukull WA, Lah JJ, Larson EB, Levey AI, Lieberman AP, Lopez OL, Lunetta KL, Mack WJ, Marson DC, Martin ER, Martiniuk F, Mash DC, Masliah E, McCormick WC, McCurry SM, McDavid AN, McKee AC, Mesulam M, Miller BL, Miller CA, Miller JW, Montine TJ, Morris JC, Naj AC, Nowotny P, Parisi JE, Peskind E, Petersen RC, Poon WW, Potter H, Quinn JF, Raj A, Rajbhandary RA, Raskind M, Reisberg B, Reitz C, Ringman JM, Roberson ED, Rogaeva E, Rosenberg RN, Sano M, Saykin AJ, Schneider JA, Schneider LS, Seeley WW, Shelanski ML, Smith CD, Sonnen JA, Spina S, St George-Hyslop P, Stern RA, Tanzi RE, Trojanowski JQ, Troncoso JC, Tsuang DW, Valladares O, Van Deerlin VM, Vardarajan BN, Vinters HV, Vonsattel JP, Wang LS, Weintraub S, Welsh-Bohmer KA, Williamson J, Woltjer RL, Wright CB, Younkin SG (2013) Initial assessment of the pathogenic mechanisms of the recently identified Alzheimer risk loci. Ann Hum Genet 77(2):85-105. doi:10.1111/ahg.12000

45. Guerreiro R, Wojtas A, Bras J, Carrasquillo M, Rogaeva E, Majounie E, CruchagaC, Sassi C, Kauwe JS, Younkin S, Hazrati L, Collinge J, Pocock J, Lashley T,Williams J, Lambert JC, Amouyel P, Goate A, Rademakers R, Morgan K, Powell J, St George-Hyslop P, Singleton A, Hardy J; Alzheimer Genetic Analysis Group (2013) TREM2 variants in Alzheimer's disease. N Engl J Med 368(2):117-127. doi:10.1056/NEJMoa1211851

46. Jonsson T, Stefansson H, Steinberg S, Jonsdottir I, Jonsson PV, Snaedal J, Bjornsson S, Huttenlocher J, Levey AI, Lah JJ, Rujescu D, Hampel H, Giegling I, Andreassen OA, Engedal K, Ulstein I, Djurovic S, Ibrahim-Verbaas C, Hofman A, Ikram MA, van Duijn CM, Thorsteinsdottir U, Kong A, Stefansson K (2013) Variant of TREM2 associated with the risk of Alzheimer's disease. N Engl J Med 368(2):107-116. doi:10.1056/NEJMoa 1211103

47. Jonsson T, Atwal JK, Steinberg S, Snaedal J, Jonsson PV, Bjornsson S, Stefansson H, Sulem P, Gudbjartsson D, Maloney J, Hoyte K, Gustafson A, Liu Y, Lu Y, Bhangale T, Graham RR, Huttenlocher J, Bjornsdottir G, Andreassen OA, Jönsson EG, Palotie A, Behrens TW, Magnusson OT, Kong A, Thorsteinsdottir U, Watts RJ, Stefansson K (2012) A mutation in APP protects against Alzheimer's disease and age-related cognitive decline. Nature 488(7409):96-99. doi:10.1038/nature11283

48. Kero M, Paetau A, Polvikoski T, Tanskanen M, Sulkava R, Jansson L, Myllykangas L, Tienari PJ (2013) Amyloid precursor protein (APP) A673T mutation in the elderly Finnish population. Neurobiol Aging 34(5):1518.e1-3. doi:10.1016/j.neurobiolaging. 2012.09.017

49. Goldman JS (2012) New approaches to genetic counseling and testing for Alzheimer's disease and frontotemporal degeneration. Curr Neurol Neurosci Rep 12(5):502-510. doi:10.1007/s11910012-0296-1

50. Kwon JM, Steiner RD (2011) “I'm fine; I'm just waiting for my disease": the new and growing class of presymptomatic patients. Neurology 77(6):522-523. doi:10.1212/WNL.0b013e $318228 \mathrm{c} 15 \mathrm{f}$ 
51. Karlawish J (2011) Addressing the ethical, policy, and social challenges of preclinical Alzheimer disease. Neurology 77(15):1487-1493. doi:10.1212/WNL.0b013e318232ac1a

52. Ostrowitzki S, Deptula D, Thurfjell L, Barkhof F, Bohrmann B, Brooks DJ, Klunk WE, Ashford E, Yoo K, Xu ZX, Loetscher H, Santarelli L (2012) Mechanism of amyloid removal in patients with Alzheimer disease treated with gantenerumab. Arch Neurol 69(2):198-207. doi:10.1001/archneurol.2011.1538

53. Rosenberg RN (2011) Treat Alzheimer disease before it is symptomatic. Arch Neurol 68(10):1237-1238. doi:10.1001/arch neurol.2011.135

54. Kennedy AM, Frackowiak RSJ, Newman SK, Bloomfield PM, Seaward J, Roques P, Lewington G, Cunningham VJ, Rossor MN (1995) Deficits in cerebral glucose metabolism demonstrated by positron emission tomography in individuals at risk of familial Alzheimer's disease. Neurosci Lett 186:17-20. doi:10.1016/ 0304-3940(95)11270-7

55. Kaiser NC, Melrose RJ, Liu C, Sultzer DL, Jimenez E, Su M, Monserratt L, Mendez MF (2012) Neuropsychological and neuroimaging markers in early versus late-onset Alzheimer's disease. Am J Alzheimers Dis Other Demen 27(7):520-529. doi: $10.1177 / 1533317512459798$

56. Rossor MN, Kennedy AM, Frackowiak RSJ (1996) Clinical and neuroimaging features of familial Alzheimer's disease. Ann N Y Acad Sci 17:49-56. doi:10.1111/j.1749-6632.1996. tb34400.x

57. Nikisch G, Hertel A, Kiessling B, Wagner T, Krasz D, Hofmann E, Wiedemann G (2008) Three-year follow-up of a patient with early-onset Alzheimer's disease with presenilin-2 N141I mutation-case report and review of the literature. Eur J Med Res 13:579-584

58. Jack CR Jr, Knopman DS, Jagust WJ, Shaw LM, Aisen PS, Weiner MW, Petersen RC, Trojanowski JQ (2010) Hypothetical model of dynamic biomarkers of the Alzheimer's pathological cascade. Lancet Neurol 9(1):119-128. doi:10.1016/S1474-4422 (09)70299-6

59. Reiman EM, Caselli RJ, Yun LS, Chen K, Bandy D, Minoshima S, Thibodeau SN, Osborne D (1996) Preclinical evidence of Alzheimer's disease in persons homozygous for the epsilon 4 allele for apolipoprotein E. N Engl J Med 334:752-758. doi: 10.1056/NEJM199603213341202

60. Mosconi L, Herholz K, Prohovnik I, Nacmias B, De Cristofaro MT, Fayyaz M, Bracco L, Sorbi S, Pupi A (2005) Metabolic interaction between APOE genotype and onset age in Alzheimer disease: implications for brain reserve. J Neurol Neurosurg Psychiatry 76:15-23. doi:10.1136/jnnp.2003.030882

61. Mosconi L, De Santi S, Brys M, Tsui WH, Pirraglia E, GlodzikSobanska L, Rich KE, Switalski R, Mehta PD, Pratico D, Zinkowski R, Blennow K, de Leon MJ (2008) Hypometabolism and altered cerebrospinal fluid markers in normal apolipoprotein E4 carriers with subjective memory complaints. Biol Psychiatry 63(6):609-618. doi:10.1016

62. Reiman EM, Caselli RJ, Chen K, Alexander GE, Bandy D, Frost J (2001) Declining brain activity in cognitively normal apolipoprotein E epsilon 4 heterozygotes: a foundation for using positron emission tomography to efficiently test treatments to prevent Alzheimer's disease. Proc Natl Acad Sci USA 98(6):3334-3339. doi:10.1073/pnas.061509598

63. Reiman EM, Caselli RJ, Alexander GE, Chen K (2001b) Tracking the decline in cerebral glucose metabolism in persons and laboratory animals at genetic risk for Alzheimer's disease. Clin Neurosci Res 1(3):194-206. doi:10.1016/S1566-2772(01)00006-8

64. Reiman EM, Chen K, Alexander GE, Caselli RJ, Bandy D, Osborne D, Saunders AM, Hardy J (2004) Functional brain abnormalities in young adults at genetic risk for late-onset
Alzheimer's dementia. Proc Natl Acad Sci USA 101(1):284-289. doi:10.1073/pnas.2635903100

65. Mosconi L, Perani D, Sorbi S, Herholz K, Nacmias B, Holthoff V, Salmon E, Baron JC, De Cristofaro MT, Padovani A, Borroni B, Franceschi M, Bracco L, Pupi A (2004) MCI conversion to dementia and the APOE genotype: a prediction study with FDGPET. Neurology 63:2332-2340. doi:10.1212/01.WNL.00001474 69.18313.3B

66. Ossenkoppele R, van der Flier WM, Zwan MD, Adriaanse SF, Boellaard R, Windhorst AD, Barkhof F, Lammertsma AA, Scheltens P, van Berckel BN (2013) Differential effect of APOE genotype on amyloid load and glucose metabolism in AD dementia. Neurology 80(4):359-365. doi:10.1212/WNL.0b013e $31827 f 0889$

67. Mosconi L, Brys M, Switalski R, Mistur R, Glodzik-Sobanska L, Pirraglia E, Tsui W, De Santi S, de Leon MJ (2007) Maternal family history of Alzheimer's disease predisposes to reduced brain glucose metabolism. Proc Natl Acad Sci USA 104(48): 19067-19072. doi:10.1073/pnas.0705036104

68. Berti V, Mosconi L, Glodzik L, Li Y, Murray J, De Santi S, Pupi A, Tsui W, De Leon MJ (2011) Structural brain changes in normal individuals with a maternal history of Alzheimer's. Neurobiol Aging 32(12):2325.e17-26

69. Mosconi L, Mistur R, Glodzik L, Brys M, Switalski R, Pirraglia E, Tsui W, De Santi S, de Leon MJ (2009) Declining brain glucose metabolism in normal individuals with a maternal history of Alzheimer's. Neurology 72:513-520. doi:10.1212/01.wnl.00 00333247.51383 .43

70. Papassotiropoulos A, Stephan DA, Huentelman MJ, Hoerndli FJ, Craig DW, Pearson JV, Huynh KD, Brunner F, Corneveaux J, Osborne D, Wollmer MA, Aerni A, Coluccia D, Hänggi J, Mondadori CR, Buchmann A, Reiman EM, Caselli RJ, Henke K, de Quervain DJ (2006) Common Kibra alleles are associated with human memory performance. Science 314:475-478. doi: $/ 10.1126 /$ science. 1129837

71. Nacmias B, Bessi V, Bagnoli S, Tedde A, Cellini E, Piccini C, Sorbi S, Bracco L (2008) KIBRA gene variants are associated with episodic memory performance in subjective memory complaints. Neurosci Lett 436(2):145-147. doi:10.1016/j.neulet. 2008.03.008

72. Corneveaux JJ, Liang WS, Reiman EM, Webster JA, Myers AJ, Zismann VL, Joshipura KD, Pearson JV, Hu-Lince D, Craig DW, Coon KD, Dunckley T, Bandy D, Lee W, Chen K, Beach TG, Mastroeni D, Grover A, Ravid R, Sando SB, Aasly JO, Heun R, Jessen F, Kölsch H, Rogers J, Hutton ML, Melquist S, Petersen RC, Alexander GE, Caselli RJ, Papassotiropoulos A, Stephan DA, Huentelman MJ (2010) Evidence for an association between KIBRA and late-onset Alzheimer's disease. Neurobiol Aging 31(6):901-909. doi:10.1016/j.neurobiolaging.2008.07.014

73. Mackenzie IR, Rademakers R, Neumann M (2010) TDP-43 and FUS in amyotrophic lateral sclerosis and frontotemporal dementia. Lancet Neurol 9(10):995-1007. doi:10.1016/S14744422(10)70195-2

74. Rascovsky K, Hodges JR, Knopman D, Mendez MF, Kramer JH, Neuhaus J, van Swieten JC, Seelaar H, Dopper EG, Onyike CU, Hillis AE, Josephs KA, Boeve BF, Kertesz A, Seeley WW, Rankin KP, Johnson JK, Gorno-Tempini ML, Rosen H, PrioleauLatham CE, Lee A, Kipps CM, Lillo P, Piguet O, Rohrer JD, Rossor MN, Warren JD, Fox NC, Galasko D, Salmon DP, Black SE, Mesulam M, Weintraub S, Dickerson BC, Diehl-Schmid J, Pasquier F, Deramecourt V, Lebert F, Pijnenburg Y, Chow TW, Manes F, Grafman J, Cappa SF, Freedman M, Grossman M, Miller BL (2011) Sensitivity of revised diagnostic criteria for the behavioural variant of frontotemporal dementia. Brain 134(Pt 9):2456-2477. doi:10.1093/brain/awr179 
75. Gorno-Tempini ML, Hillis AE, Weintraub S, Kertesz A, Mendez M, Cappa SF, Ogar JM, Rohrer JD, Black S, Boeve BF, Manes F, Dronkers NF, Vandenberghe R, Rascovsky K, Patterson K, Miller BL, Knopman DS, Hodges JR, Mesulam MM, Grossman M (2011) Classification of primary progressive aphasia and its variants. Neurology 76(11):1006-1014. doi:10.1212/WNL.0b 013e31821103e6

76. Lynch T, Sano M, Marder KS, Bell KL, Foster NL, Defendini RF, Sima AA, Keohane C, Nygaard TG, Fahn S et al (1994) Clinical characteristics of a family with chromosome 17-linked disinhibition-dementia-parkinsonism-amyotrophy complex. Neurology 44(10):1878-1884. doi:10.1212/WNL.44.10.1878

77. DeJesus-Hernandez M, Mackenzie IR, Boeve BF, Boxer AL, Baker M, Rutherford NJ, Nicholson AM, Finch NA, Flynn H, Adamson J, Kouri N, Wojtas A, Sengdy P, Hsiung GY, Karydas A, Seeley WW, Josephs KA, Coppola G, Geschwind DH, Wszolek ZK, Feldman H, Knopman DS, Petersen RC, Miller BL, Dickson DW, Boylan KB (2011) Expanded GGGGCC hexanucleotide repeat in noncoding region of C9ORF72 causes chromosome 9p-linked FTD and ALS. Neuron 72(2):245-256. doi: 10.1016/j.neuron.2011.09.011

78. Renton AE, Majounie E, Waite A, Simón-Sánchez J, Rollinson S, Gibbs JR, Schymick JC, Laaksovirta H, van Swieten JC, Myllykangas L, Kalimo H, Paetau A, Abramzon Y,Remes AM, Kaganovich A, Scholz SW, Duckworth J, Ding J, Harmer DW, Hernandez DG, Johnson JO, Mok K, Ryten M, Trabzuni D, Guerreiro RJ, Orrell RW, Neal J, Murray A, Pearson J, Jansen IE, Sondervan D, Seelaar H, Blake D, Young K, Halliwell N,Callister JB, Toulson G, Richardson A, Gerhard A, Snowden J, Mann D, Neary D,Nalls MA, Peuralinna T, Jansson L, Isoviita VM, Kaivorinne AL, Hölttä-Vuori M,Ikonen E, Sulkava R, Benatar M, Wuu J, Chiò A, Restagno G, Borghero G, Sabatelli M; ITALSGEN Consortium, Heckerman D, Rogaeva E, Zinman L, Rothstein JD, Sendtner M, Drepper C, Eichler EE, Alkan C, Abdullaev Z, Pack SD, Dutra A, Pak E, Hardy J,Singleton A,
Williams NM, Heutink P, Pickering-Brown S, Morris HR, Tienari PJ,Traynor BJ (2011) A hexanucleotide repeat expansion in C9ORF72 is the cause of chromosome 9p21-linked ALS-FTD. Neuron 72(2):257-268. doi:10.1016/j.neuron.2011.09.010

79. Rademakers R, Neumann M, Mackenzie IR (2012) Advances in understanding the molecular basis of frontotemporal dementia. Nat Rev Neurol 423-434. doi:10.1038/nrneurol.2012.117

80. Mori K, Weng SM, Arzberger T, May S, Rentzsch K, Kremmer E, Schmid B, Kretzschmar HA, Cruts M, Van Broeckhoven C, Haass C, Edbauer D (2013) The C9orf72 GGGGCC repeat is translated into aggregating dipeptide-repeat proteins in FTLD/ ALS. Science 339(6125):1335-1338. doi:10.1126/science.12 32927

81. Le Ber I, Camuzat A, Guillot-Noel L, Hannequin D, Lacomblez L, Golfier V, Puel M, Martinaud O, Deramecourt V, RivaudPechoux S, Millecamps S, Vercelletto M, Couratier P, Sellal F, Pasquier F, Salachas F, Thomas-Antérion C, Didic M, Pariente J, Seilhean D, Ruberg M, Wargon I, Blanc F, Camu W, Michel BF, Berger E, Sauvée M, Thauvin-Robinet C, Mondon K, TournierLasserve E, Goizet C, Fleury M, Viennet G, Verpillat P, Meininger V, Duyckaerts C, Dubois B, Brice A (2013) C9ORF72 repeat expansions in the frontotemporal dementias spectrum of diseases: a flow-chart for genetic testing. J Alzheimers Dis 34(2):485-499. doi:10.3233/JAD-121456

82. McDade E, Boeve BF, Burrus TM, Boot BP, Kantarci K, Fields J, Lowe VJ, Peller P, Knopman D, Baker M, Finch N, Rademakers R, Petersen R (2012) Similar clinical and neuroimaging features in monozygotic twin pair with mutation in progranulin. Neurology 78(16):1245-1249. doi:10.1212/WNL.0b013e318251594c

83. Adeli A, Savica R, Lowe VJ, Vemuri P, Knopman DS, DejesusHernandez M, Rademakers R, Fields JA, Crum BA, Jack CR, Petersen RC, Boeve BF (2012) The GGGGCC repeat expansion in C9ORF72 in a case with discordant clinical and FDG-PET findings: PET Trumps syndrome. Neurocase (Epub ahead of print) 